\title{
Patients with Covid 19 have significantly reduced CH50 activity
}

\author{
Fatemeh Keshavarz $^{1} \cdot$ Farideh Ghalamfarsa $^{2} \cdot$ Saeed Javdansirat $^{3}$. \\ Sajad Hasanzadeh ${ }^{3} \cdot$ Arsalan Azizi $^{4} \cdot$ Gholamabbas Sabz $^{3} \cdot$ Marziyeh Salehi $^{3}$. \\ Ghasem Ghalamfarsa ${ }^{3}$
}

Received: 4 March 2021 / Accepted: 8 June 2021/Published online: 2 October 2021

(C) Indian Virological Society 2021

\begin{abstract}
Severe acute respiratory syndrome coronavirus 2 (SARS-CoV-2), which causes coronavirus disease 2019 (COVID-19), is a new virus that emerged in China and immediately spread around the world. Evidence has been documented that the immune system is impressively involved in the pathogenesis of this disease, especially in causing inflammation. One of the important components of the immune system is the complement system whose increased activity has been shown in inflammatory diseases and consequently damage caused by the activity of its components. In the present study, serum levels of C3 and $\mathrm{C} 4$ factors as well as the activity level of complement system in the classical pathway were measured by $\mathrm{CH} 50$ test in patients with SARS-CoV-2. Participants in the study consisted of 53 hospitalized patients whose real-time PCR test was positive for SARS-CoV-2. The mean age of these patients was $42.06 \pm 18.7$ years, including $40 \%$ women and $60 \%$ men. The most common symptoms in these patients were cough (70\%), fever (59\%), dyspnea (53\%) and chills (53\%), respectively. Analysis of biochemical and hematological test results revealed that $26(49 \%)$ patients had lymphopenia, $34(64 \%)$ patients were positive for
\end{abstract}

Ghasem Ghalamfarsa

ghasem_ghalamfarsa@yahoo.com

1 Cellular and Molecular Research Center, Shahrekord University of Medical Sciences, Shahrekord, Iran

2 Department of Medical Biotechnology, School of Advanced Medical Sciences and Technologies, Shiraz University of Medical Sciences, Shiraz, Iran

3 Medicinal Plants Research Center, Yasuj University of Medical Sciences, Yasuj, Iran

4 Cellular and Molecular Research Center, Yasuj University of Medical Sciences, Yasuj, Iran
C-reactive protein (CRP) and 26 (49\%) patients had ESR and LDH levels significantly higher than normal. In addition, 27 patients $(51 \%)$ had vitamin $\mathrm{D}$ deficiency. The mean CH50 activity level in COVID-19 patients was significantly reduced compared to healthy individuals (84.9 versus $169.9 \mathrm{U} / \mathrm{ml}, p=<0.0001)$. Comparison of the mean CH50 activity levels between different subgroups of patients indicated that COVID-19 patients with decreased peripheral blood lymphocyte count and positive CRP had a significant increase in activity compared to the other groups $(p=0.0002)$. The serum levels of $\mathrm{C} 3$ and $\mathrm{C} 4$ factors had no significant change between patients and healthy individuals. Conclusion: The activity level of complement system in the classical pathway decreases in COVID-19 patients compared to healthy individuals, due to increased activity of complement system factors in these patients.

Keywords Covid-19 · CH50 · Complement system

\section{Introduction}

A new emerging viral infection was transmitted from animal to human and then human to human in Wuhan, China in December 2019, leading to a global epidemic [1]. Acute Respiratory Syndrome is a hallmark of this new virus, known as severe acute respiratory syndrome coronavirus 2 , SARS-CoV-2 [2]. Following the global outbreak, the World Health Organization (WHO) declared a global health emergency on January 30, 2020 [3]. By December 2020, according to WHO data, more than 75 million people had been infected with COVID-19, as well as more than 1.6 million deaths from the virus worldwide [4]. The symptoms of this disease are very diverse and are seen in a wide range of different organs of the body, including fever, 
dry cough, dyspnea, cardiopulmonary complications, headache, lymphopenia, elevated lactate dehydrogenase, coagulation disorders, increased liver enzymes, fatigue, myalgia, secondary infections, acute kidney injury and even death in severe cases $[5,6]$. It should be noted that $80 \%$ of patients infected with SARS-CoV-2 have mild symptoms and a good prognosis and recover with standard treatments or without drug intervention, but about $20 \%$ of patients suffer from respiratory distress and require oxygen therapy or other inpatient interventions, including mechanical ventilation [7].

The main site of the viral establishment in the body is lung tissue, but it can spread to other organs and cause multiple organ failure, MOF [8]. Tissue damage caused by COVID-19 is not primarily related to viral infection but is the result of inflammatory responses of the host immune system, which cause a hyperactivity of the innate immune system, increased cytokines and chemokines, and immune cell utilization and thus a cytokine storm, affecting the cells in lung parenchyma and reducing oxygen uptake $[8,9]$.

The complement system is a network consisting of 50 different proteins as part of the innate immune system, which plays an essential role in host defense against pathogens and in tissue homeostasis [10]. The complement system can be activated from three pathways including the classical pathway, the lectin-dependent pathway and the alternative pathway. Cleavage of complement $\mathrm{C} 3$ by enzymes of these pathways (the $\mathrm{C} 3$-converting enzyme) causes the formation of other components of complement system, including C3a, C3b, C4a and C4b, whose functions are the elimination of pathogens through opsonization and uptake and activation of neutrophils and macrophages as well as the enhancement of humoral immunity and $\mathrm{T}$ cell response [8]. Further formation of $\mathrm{C} 3 \mathrm{~b}$ leads to the production of C5 converter, which causes the production of $\mathrm{C} 5 \mathrm{a}$ and $\mathrm{C} 5 \mathrm{~b}$ from $\mathrm{C} 5$. Anaphylatoxin fragments of $\mathrm{C} 3 \mathrm{a}$ C5a cause the recruitment and activation of immune cells and the secretion of inflammatory cytokines such as TNF$\alpha$, IL-1 $\beta$ and IL- 6 from these cells and provide a pre-inflammatory condition. The C5b forms a complex with other complement proteins called the membrane attack complex (MAC or C5b-9), the deposition of which on the cell membrane leads to cell lysis [11, 12]. Immune system exposure to SARS coronavirus, which is closely related to SARS-CoV-2, has been shown to significantly increase complement system activity and exacerbate inflammation [13].

In other models of rodents infected with Middle East Respiratory Syndrome coronavirus (MERS-CoV), an increase in serum and lung $\mathrm{C} 5 \mathrm{a}$ and $\mathrm{C} 5 \mathrm{~b}-9$ concentrations was observed, and blocking the C5a and C5aR pathways reduced tissue damage [14]. In addition, evidence suggests that polymorphisms in the $\mathrm{C} 3$ gene may be effective in the prevalence and spread of SARS-CoV-2 [15].

The aim of this study was to evaluate the serum levels of C3, C4 and CH50 from the complement system, biochemical factors, hematological parameters, clinical symptoms as well as serum levels of vitamin D in hospitalized SARS-CoV-2 patients with positive real-time PCR test for SARS-CoV-2 to better identify the pathways involved in the pathogenesis of the virus and use the results to design effective treatment, reduce complications or inhibit inflammation in infected people with the virus.

\section{Materials and methods}

The present cross-sectional study was conducted in November 2020 on COVID-19 patients admitted to Shahid Dr. Jalil Yasuj Hospital in southern Iran. From 53 eligible patients whose real-time PCR test was positive for COVID19 , after obtaining written consent, $10 \mathrm{ml}$ of venous blood samples were taken from all patients and their serum was separated in the laboratory and stored at $-70{ }^{\circ} \mathrm{C}$ until next testing. All clinical, demographic, biochemical and hematological data of patients were recorded (Tables 1, 2, 3). Absolute lymphocyte count (ALC) below 1500 cells/microliter was considered as lymphopenia. Hemoglobin levels below $12 \mathrm{~g} / \mathrm{dL}$ in women and below $13.5 \mathrm{~g} / \mathrm{dL}$ in men were considered as anemia. Platelet counts less than 150,000 are termed thrombocytopenia. C-reactive protein (CRP) was measured qualitatively (negative, $1+, 2+$ and $3+)$. ESR $(\mathrm{mm} / \mathrm{h})$ was regarded normal in men up to 15 and in women up to 20 . LDH up to $400 \mathrm{U} / \mathrm{L}$ and CPK up to $194 \mathrm{U} / \mathrm{L}$ were considered normal. AST in women up to $31 \mathrm{mg} / \mathrm{dl}$ and in men up to $38 \mathrm{mg} / \mathrm{dl}$ and ALT in women up to $32 \mathrm{mg} / \mathrm{dl}$ and in men up to $40 \mathrm{mg} / \mathrm{dl}$ were considered normal ranges. Total bilirubin up to $1.2 \mathrm{mg} / \mathrm{dl}$, direct bilirubin up to $0.3 \mathrm{mg} / \mathrm{dl}$ and albumin up to $5 \mathrm{~g} / \mathrm{dl}$ were considered normal.

\section{Measurement of vitamin D}

The Vit D level was measured using ELISA kit (Pishgaman Company, Iran) based on the principle of competitive bonding. In this method, the wells were coated by antiVitamin D $(25 \mathrm{OH})$ monoclonal antibody. After the exposure of standards, controls and patient samples with wells, finally the optical density (OD) was read at a wavelength of $450 \mathrm{~nm}$. The relationship between color intensity and Vit D level in the sample is inverse. According to the range in the kit, the Vit D level up to $20 \mathrm{ng} / \mathrm{ml}$ was considered sufficient. 
Table 1 Laboratory findings of patients including CBC, biochemical tests, serum Vitamin D levels and blood type are reported

\begin{tabular}{|c|c|c|c|}
\hline \multirow[t]{19}{*}{ Laboratory findings } & $\mathrm{CBC}$ & Lymphopenia (number, \%) & $25(47.16 \%)$ \\
\hline & & Anemia (number, \%) & $7(13.2 \%)$ \\
\hline & & Thrombocytopenia (number, \%) & $7(13.2 \%)$ \\
\hline & Acute phase reactant & Elevated ESR & $26(49.05 \%)$ \\
\hline & & Positive CRP & $34(64.15 \%)$ \\
\hline & Blood chemistries & Elevated AST & $4(7.54 \%)$ \\
\hline & & Elevated ALT & $8(15.09 \%)$ \\
\hline & & Elevated ALB & $8(15.09 \%)$ \\
\hline & & Elevated CPK & $11(20.75 \%)$ \\
\hline & & Elevated LDH & $26(49.05 \%)$ \\
\hline & & Raised Creatinine & $6(11.32 \%)$ \\
\hline & & Raised BUN & $10(18.86 \%)$ \\
\hline & & Hyperbilirubinemia & $11(20.75 \%)$ \\
\hline & & Positive troponin & $1(1.88 \%)$ \\
\hline & Hormonal test & Vitamin D deficiency & $27(50.27 \%)$ \\
\hline & Blood group & $\mathrm{O}+$ & $19(35.85 \%)$ \\
\hline & & $\mathrm{A}+$ & $15(28.30 \%)$ \\
\hline & & $\mathrm{B}+$ & $14(26.41 \%)$ \\
\hline & & Other blood group & $5(9.43 \%)$ \\
\hline
\end{tabular}

Table 2 Findings related to CT scan and the extent of lung involvement in patients

\begin{tabular}{lll}
\hline Lung CT scan findings & Bilateral and mild & $19(35.85 \%)$ \\
& One-sided and mild & $5(9.43 \%)$ \\
& One-side and sever & $3(5.66 \%)$ \\
& Bilateral and serve & $9(16.98 \%)$ \\
& Normal & $17(32.07 \%)$ \\
\hline
\end{tabular}

\section{Measurement of serum $\mathrm{C} 3$ and $\mathrm{C} 4$ levels and CH50 activity}

Factors C3 and C4 were measured using Biobase kits. In summary, C3 and C4 formed immunocomplexes with specific latex-bonded antibodies, and the turbidity resulting from this reaction was measured by nephlometry at $340 \mathrm{~nm}$. According to the kit manufacturer's instructions, the normal range of $\mathrm{C} 3$ and $\mathrm{C} 4$ is $0.82-1.80 \mathrm{~g} / \mathrm{l}$ and 0.1-0.4 g/l, respectively. The CH50 activity levels were measured using Mybiosource ELISA kits (Human 50\% complement hemolysis (CH50) ELISA Kit). This kit uses the Double Antibody Sandwich technique. The method of working with this kit was according to the manufacturer's 09.3.1 instructions for measuring $\mathrm{CH} 50$.

\section{Measurement of CRP}

Biogene kit was used to measure CRP. The technique is based on passive agglutination. In this technique, latex particles are coated with anti-CRP antibody, which in the presence of CRP in the serum of individuals, antigen-antibody binding is done and the result will be clear in the form of agglutination. The absence of CRP in the serum will not lead to any agglutination. Finally, the result was reported qualitatively:

- Large and very clear agglutination with clear background: +3

- Clear and moderate agglutination with clear background: +2

- Visible and fine agglutination with milky background: +1

- Milky and uniform suspension and no agglutination: Negative

\section{Statistical analysis}

Data were analyzed by SPSS 26 and Graph pad prism 8.4.3 software. Relationships were determined using Mann Whitney test, Unpaired t-test and One-way ANOVA tests. 
Table 3 Clinical signs and symptoms of patients

\begin{tabular}{|c|c|c|c|c|c|c|c|c|c|c|c|c|}
\hline Patient & $\begin{array}{l}\text { Degree of } \\
\text { disease } \\
\text { severity }\end{array}$ & Fever & Chills & Headache & Dyspnea & Cough & $\begin{array}{l}\text { Nausea } \\
\text { and } \\
\text { Vomiting }\end{array}$ & Diarrhea & $\begin{array}{l}\text { Lack of } \\
\text { smell } \\
\text { and taste }\end{array}$ & Myalgia & $\begin{array}{l}\text { Chest } \\
\text { pain }\end{array}$ & $\begin{array}{l}\text { Underlying } \\
\text { disease }\end{array}$ \\
\hline $\mathrm{P} 1$ & Mild & $*$ & $*$ & $*$ & $*$ & $*$ & $*$ & $*$ & & $*$ & $*$ & Diabetes \\
\hline $\mathrm{P} 2$ & Mild & $*$ & $*$ & $*$ & $*$ & $*$ & $*$ & & & & & \\
\hline P3 & Mild & $*$ & $*$ & $*$ & $*$ & $*$ & & $*$ & & & & Gout \\
\hline $\mathrm{P} 4$ & Moderate & $*$ & $*$ & $*$ & $*$ & $*$ & $*$ & $*$ & & & & $\begin{array}{l}\text { High blood } \\
\text { pressure }\end{array}$ \\
\hline P5 & Mild & $*$ & $*$ & $*$ & $*$ & $*$ & & & & & & $\begin{array}{l}\text { High blood } \\
\text { pressure }\end{array}$ \\
\hline P6 & Mild & & & & $*$ & $*$ & & & & $*$ & & \\
\hline $\mathrm{P} 7$ & Mild & & & $*$ & $*$ & & $*$ & & & & $*$ & \\
\hline P8 & Mild & $*$ & & $*$ & & $*$ & & $*$ & & $*$ & & \\
\hline P9 & Moderate & $*$ & $*$ & $*$ & $*$ & $*$ & $*$ & $*$ & & & $*$ & \\
\hline $\mathrm{P} 10$ & Mild & & & & $*$ & $*$ & & & & $*$ & & \\
\hline P11 & Mild & $*$ & & & $*$ & $*$ & & & & & & \\
\hline $\mathrm{P} 12$ & Mild & $*$ & & & & & & & $*$ & & & $\begin{array}{l}\text { High blood } \\
\text { pressure }\end{array}$ \\
\hline P13 & Mild & & & & $*$ & $*$ & & & & & & $\begin{array}{l}\text { High blood } \\
\text { pressure }\end{array}$ \\
\hline P14 & Mild & & & & $*$ & $*$ & & & & & & \\
\hline P15 & Mild & & & & & $*$ & & & & & & \\
\hline P16 & Mild & $*$ & $*$ & & & $*$ & & & & & & \\
\hline P17 & Mild & $*$ & $*$ & & & $*$ & & & & & & \\
\hline P18 & Mild & $*$ & $*$ & & & $*$ & & & & & & \\
\hline P19 & Mild & $*$ & $*$ & & & $*$ & & & $*$ & & & Smoker \\
\hline $\mathrm{P} 20$ & Mild & $*$ & $*$ & $*$ & $*$ & $*$ & & & $*$ & & & $\begin{array}{c}\text { High blood } \\
\text { pressure- } \\
\text { Diabetes }\end{array}$ \\
\hline $\mathrm{P} 21$ & Mild & $*$ & $*$ & & $*$ & $*$ & & & & & & \\
\hline $\mathrm{P} 22$ & Mild & & & & & & & & & & & \\
\hline $\mathrm{P} 23$ & Mild & $*$ & $*$ & $*$ & $*$ & $*$ & $*$ & $*$ & $*$ & $*$ & & $\begin{array}{l}\text { High blood } \\
\text { pressure }\end{array}$ \\
\hline $\mathrm{P} 24$ & Mild & $*$ & $*$ & & $*$ & & & & & $*$ & & \\
\hline $\mathrm{P} 25$ & Severe & & & & $*$ & $*$ & & & & & $*$ & CKD \\
\hline $\mathrm{P} 26$ & Mild & & & $*$ & & $*$ & & & & $*$ & & \\
\hline $\mathrm{P} 27$ & Mild & & & & & & & & & & & \\
\hline $\mathrm{P} 28$ & Mild & & & $*$ & & & $*$ & & & & $*$ & \\
\hline P29 & Mild & & $*$ & & & $*$ & & & & & & \\
\hline P30 & Mild & $*$ & $*$ & $*$ & & $*$ & & & & & & \\
\hline $\mathrm{P} 31$ & Mild & $*$ & $*$ & $*$ & $*$ & $*$ & & & & & $*$ & \\
\hline P32 & Mild & $*$ & $*$ & & $*$ & $*$ & & & & & & \\
\hline P33 & Mild & $*$ & & & & & & $*$ & & & & \\
\hline P34 & Mild & & & $*$ & $*$ & $*$ & & & & & & $\begin{array}{l}\text { Diabetes- } \\
\text { Hypothyroidism }\end{array}$ \\
\hline P35 & Moderate & $*$ & $*$ & $*$ & $*$ & $*$ & $*$ & & & & $*$ & Osteoporosis \\
\hline P36 & Mild & $*$ & $*$ & $*$ & $*$ & $*$ & $*$ & $*$ & & & & \\
\hline P37 & Mild & $*$ & $*$ & & & $*$ & & & & $*$ & & Diabetes \\
\hline P38 & Mild & & & & & $*$ & $*$ & $*$ & & & & \\
\hline P39 & Mild & $*$ & $*$ & $*$ & & $*$ & & $*$ & & $*$ & & Blood pressure \\
\hline P40 & Mild & & & & & & & & & & $*$ & Diabetes \\
\hline
\end{tabular}


Table 3 continued

\begin{tabular}{|c|c|c|c|c|c|c|c|c|c|c|c|c|}
\hline Patient & $\begin{array}{l}\text { Degree of } \\
\text { disease } \\
\text { severity }\end{array}$ & Fever & Chills & Headache & Dyspnea & Cough & $\begin{array}{l}\text { Nausea } \\
\text { and } \\
\text { Vomiting }\end{array}$ & Diarrhea & $\begin{array}{l}\text { Lack of } \\
\text { smell and } \\
\text { taste }\end{array}$ & Myalgia & $\begin{array}{l}\text { Chest } \\
\text { pain }\end{array}$ & $\begin{array}{l}\text { Underlying } \\
\text { disease }\end{array}$ \\
\hline P41 & Mild & & & & & & & & & & & $\begin{array}{c}\text { High blood } \\
\text { pressure- } \\
\text { Diabetes }\end{array}$ \\
\hline $\mathrm{P} 42$ & Mild & & & & & & & & & & & \\
\hline $\mathrm{P} 43$ & Mild & $*$ & $*$ & $*$ & & & & & & & & $\begin{array}{l}\text { Digestive } \\
\text { problems }\end{array}$ \\
\hline P44 & Mild & & & & $*$ & & & & & & & $\begin{array}{c}\text { High blood } \\
\text { pressure- } \\
\text { Diabetes }\end{array}$ \\
\hline $\mathrm{P} 45$ & Severe & $*$ & $*$ & & $*$ & $*$ & & & & & & $\begin{array}{c}\text { CHF- blood } \\
\text { pressure }\end{array}$ \\
\hline P46 & Mild & & & & $*$ & $*$ & & & & $*$ & & \\
\hline $\mathrm{P} 47$ & Mild & $*$ & $*$ & & & $*$ & & & & & & \\
\hline $\mathrm{P} 48$ & Mild & & & $*$ & & $*$ & & & & & & \\
\hline P49 & Severe & $*$ & $*$ & & $*$ & & & & $*$ & & & $\begin{array}{l}\text { Blood } \\
\text { pressure- } \\
\text { Asthma }\end{array}$ \\
\hline $\mathrm{P} 50$ & Mild & & & & & $*$ & & & & & & \\
\hline P51 & Sever & $*$ & $*$ & $*$ & $*$ & & & & & $*$ & * & $\begin{array}{l}\text { Blood } \\
\text { pressure }\end{array}$ \\
\hline P52 & Mild & & & & & & $*$ & $*$ & & & & \\
\hline P53 & Mild & $*$ & $*$ & $*$ & $*$ & & & & & & & Diabetes \\
\hline
\end{tabular}

\section{Results}

The most common symptoms in patients include cough, fever, dyspnea and chills. The study consisted of 53 patients with a mean age of $42( \pm 18.7)$, including $40 \%$ women and $60 \%$ men, as well as 53 healthy individuals were enrolled in the control group. The most common symptoms in these patients were cough $(70 \%)$, fever (59\%), dyspnea (53\%) and chills (53\%), respectively (Table 3). Analysis of biochemical and hematological test results revealed that 26 (49\%) patients had lymphopenia, 34 (64\%) patients were positive for CRP and 26 (49\%) patients had ESR and LDH levels significantly higher than normal (Table 3). The CT scan findings indicated lung involvement in $68 \%$ of patients, most of which (36\%) were bilateral and mild (Table 2). Analysis of underlying diseases in hospitalized patients showed that $40 \%$ had at least one underlying disease, which was mainly hypertension $(23 \%)$ and diabetes (15\%) (Table 3).

\section{Significant decrease in CH50 activity in COVID-19 patients}

Comparison of mean $\mathrm{CH} 50$ activity between patients and healthy individuals showed that $\mathrm{CH} 50$ activity significantly decreased (84.9 versus $169.9 \mathrm{U} / \mathrm{ml})$ in the patients $(p<0.0001)$. Although the CH50 activity was reduced in the patients, the analysis showed a significant relationship between different groups of patients and factors such as lymphocyte count and CRP level. The CH50 activity level was higher in patients with lymphopenia compared to other patients $(p=0.007)$. Moreover, a significant relationship was observed between the mean CH50 activity and CRP level $(p=0.0002)$, so that the highest level of CH50 activity was in patients with serum CRP-positive $3+$ (Fig. 1). Although the serum C3 level was increased in 17 patients $(32 \%)$ and decreased in three patients and the serum $\mathrm{C} 4$ level was elevated in 12 patients $(23 \%)$, the serum levels of $\mathrm{C} 3$ and $\mathrm{C} 4$ factors was not significantly different between healthy individuals and patients.

\section{Serum VitD3 level was significantly reduced in COVID-19 patients}

The serum VitD3 level was measured in all patients and healthy individuals, the results of which showed VitD3 deficiency in 27 patients (51\%). The comparison of mean serum VitD3 levels between healthy individuals and patients demonstrated a significant decrease in COVID-19 patients (19 versus $25 \mathrm{ng} / \mathrm{ml}, p=0.007)$ (Fig. 2). The 
Fig. 1 Mean serum CH50 activity between different groups; a Comparison of mean serum CH50 activity between COVID-19 patients and healthy individuals, indicating a significantly lower level of activity in patients than healthy individuals; b Comparison of mean CH50 activity and serum CRP level, showing the highest CH50 activity in patients with serum CRP-positive $3+$; c Mean serum CH50 activity and peripheral blood lymphocyte count in patients, exhibiting a higher mean $\mathrm{CH} 50$ activity in patients with peripheral blood lymphocyte count less than 1500 cells/ microliter; d Relationship between mean serum $\mathrm{CH} 50$ activity and neutrophil/lymphocyte ratio in patients, the higher this ratio, the higher the $\mathrm{CH} 50$ activity level a

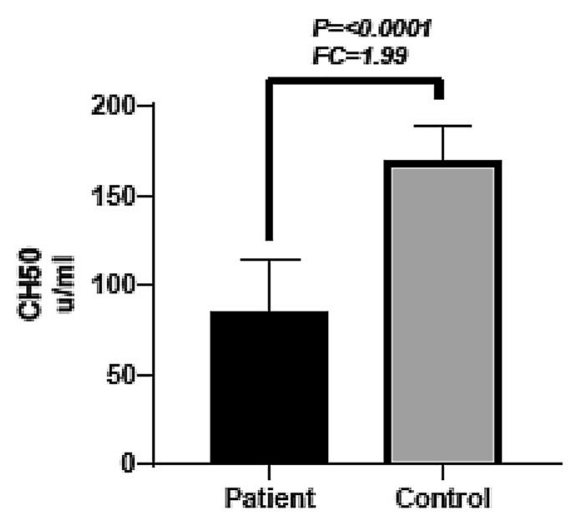

C

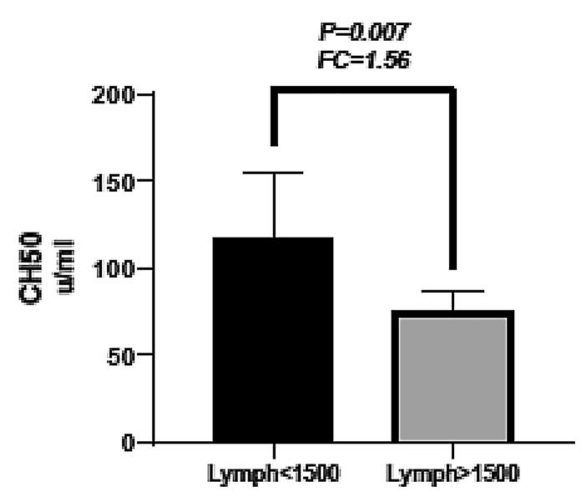

b

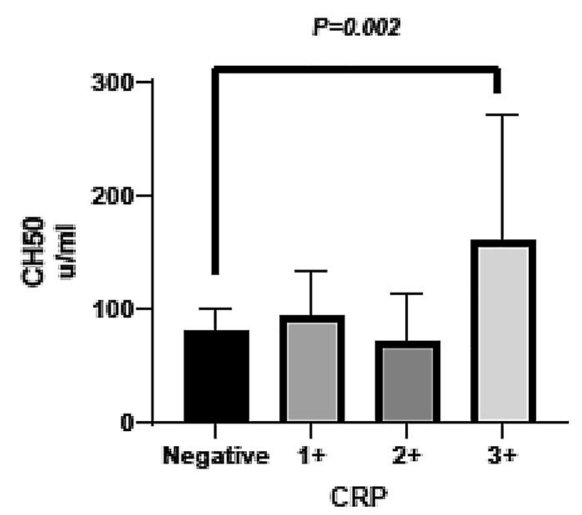

d

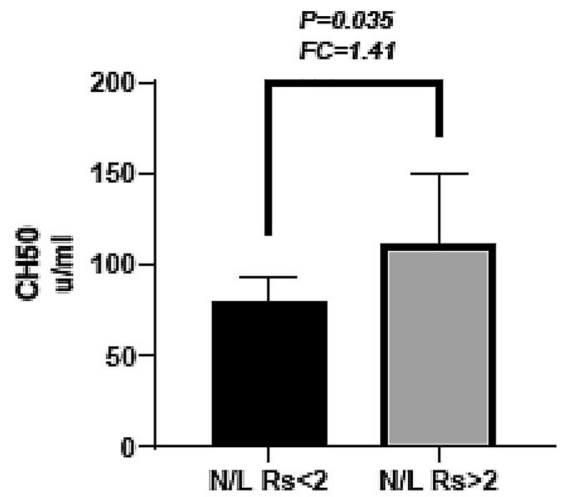

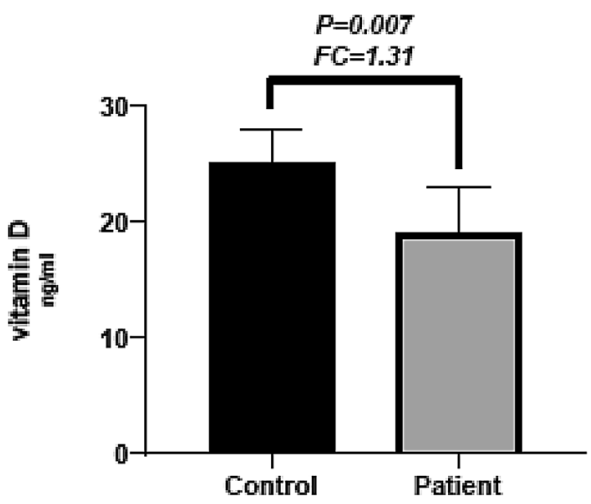

Fig. 2 Serum Vitamin D levels between control groups and COVID19 patients. As can be seen in the figure, the mean serum vitamin D level showed a significant decrease in the patient group compared to the control group

serum VitD3 level was not significantly related to the serum levels of $\mathrm{C} 3$ and $\mathrm{C} 4$ factors as well as mean CH50 activity in COVID-19 patients.

\section{Discussion}

The present study aimed to examine COVID-19 hospitalized patients. Most patients had a mild form of the disease; the most common symptoms in patients included cough, fever, dyspnea, and chills. Most clinical signs in patients in other studies reportedly were fever, cough, fatigue, headache and dyspnea. However, in patients with severe involvement, dyspnea is more common than in patients with mild to moderate form of the disease [16, 17].

In this study, it should be noted that there were two patients under 8 years of age who all had normal laboratory tests, consistent with other studies that support mild disease in children [18].

The most prevalent underlying diseases among hospitalized people are hypertension and diabetes, in line with other studies. The underlying diseases was mainly present in people over 50 years of age in the study, which is a reason for the increase in the number of hospitalizations and deaths of this group of patients. Similar studies 
reported that the majority of COVID-19 hospitalized patients had one of the underlying diseases [19-21].

In the present study, the serum levels of $\mathrm{C} 3$ and $\mathrm{C} 4$ factors as well as the level of complement system activity in the classical CH50 pathway were measured in the COVID-19 patients. According to our findings, CRP was positive in about $64 \%$ of patients' Peripheral blood C-reactive protein (CRP) is a biomarker used clinically to measure systemic inflammation [22]. In previous studies, plasma CRP levels have been positively correlated with the severity of COVID-19 pneumonia, and its levels have remained high in patients who died of Covid 19 [23, 24]. Therefore, it can be said that CRP levels are useful indicators that can accurately predict impending respiratory failure [25]. Analysis of the results revealed that the mean level of CH50 activity had increased in patients with lymphopenia and CRP-positive $3+$, indicating an increase in production and consumption of complement system components in this group of patients. The CH50 provides an estimate of the activation rate of the classical complement system pathway, which is activated by IgM and IgG antibodies and CRP when bound to antigens [26]. The level of CH50 in the patient group compared to the control group showed a significant decrease, similar to a study in northern Iran that reported hypocomplementation in one or more components of the complement system [6].

Complement is one of the major components of the innate immune system, the activation of which occurs due to the cleavage of $\mathrm{C} 3$ and $\mathrm{C} 4$ components, thereby facilitating opsonization. Moreover, this system by producing $\mathrm{C} 3 \mathrm{a}$ and C5a enhances inflammation and ultimately forms membrane attack complex (MAC) and cell lysis [27]. A study analyzed ectopic immature renal tissue (EIRT) from six COVID-19 patients and reported potent C5b-9 deposition in all six cases in the renal tubules and low C5b-9 deposition in glomerular capillaries in two cases [28]. In addition, evidence from histochemical analysis of the lung tissue of 13 patients who died from the virus exhibited the presence of C3, C4, MBL and C5b-9 complex factors in the epithelial cells of the lung alveoli and inflammatory cells [29].

In this study, the serum $\mathrm{C} 3$ and $\mathrm{C} 4$ levels were increased in a number of patients, $\mathrm{C} 3$ in $17(32.07 \%)$ patients and $\mathrm{C} 4$ in $12(22.64 \%)$, although this increase was insignificant compared to the control group.

Complement activation and improper regulation are likely to play an important role in the pathogenesis of acute lung injury caused by highly pathogenic viruses including influenza A, H1N1, H5N1, H7N9, SARS-COV and MERS [30]. In addition, the complement activation has been reported in the chronic form of hepatitis $\mathrm{C}(\mathrm{HCV})$ and there is an association between HCV pathogenesis and improper complement activity [31]. A recent study in Milan, Italy, found an increase in C5a level due to activation of the C5 fragment and an increase in the level of soluble MAC (C5b-9 s) in plasma samples of patients with severe COVID-19, confirming the hypothesis that C5 fragment blocking could be a potential treatment for COVID-19 [32]. In a study on a 71-year-old Caucasian man with a history of underlying disease and COVID-19 infection, treatment with $\mathrm{C} 3$ inhibitor significantly reduced complications of lung inflammation and improved the patient's clinical and laboratory symptoms [9]. Further, approved eculizumab, RUCONEST (C1INH) and anti-C5a and antiC3 investigational drugs have been prescribed and well tolerated in COVID-19 patients [9, 33, 34].

The serum Vit D level in the studied patients were significantly lower than in healthy individuals. In this regard, studies in different populations reported a significant relationship between Vit D levels in COVID-19 patients and healthy individuals, in line with the findings of this study that demonstrated lower Vit D level in COVID19 patients [35-38].

One of the limitations of this study is the small size of critically ill patients; it is necessary to study a larger population of patients. Given the widespread pandemic and increasing importance of COVID-19, these and other inflammatory factors and complement system anaphylatoxins, including MBL, C3a, C5a and factor D, are suggested to be measured in extensive studies on COVID-19 patients with acute and critical conditions.

\section{Conclusion}

The CH50 activity level in the patient group compared to the control group showed a significant decrease, which could indicate an increase in the activity of the classical complement pathway and a consequent decrease in the serum of infected people. The results of the present study demonstrated a significant decrease in serum Vitamin D level in patients compared to the control group. Given the strong biological evidence and relative immunity of Vitamin D supplements, it makes sense to support and apply this vitamin in this pandemic, especially for people at risk for Vitamin D deficiency. The findings from this study found no significant relationship between $\mathrm{C} 3$ and $\mathrm{C} 4$ levels in the patient and control groups. Although these two factors were increased in a number of patients, it can be said that this result was not unexpected due to the limited number of patients with severe clinical conditions in this study. 


\section{References}

1. M. Hoffmann, H. Kleine-Weber, S. Schroeder, N. K.: Cell, and undefined SARS-CoV-2 cell entry depends on ACE2 and TMPRSS2 and is blocked by a clinically proven protease inhibitor. Elsevier, 2020. https://www.sciencedirect.com/science/arti cle/pii/S0092867420302294. Accessed 25 Aug 2020

2. Fletcher-Sandersjöö A, Bellander BM. Thrombosis research, and undefined 2020 Is COVID-19 associated thrombosis caused by overactivation of the complement cascade? A literature review. Elsevier 2020. https://www.sciencedirect.com/science/article/pii/ S0049384820302693. Accessed Aug. 25, 2020

3. Bernheim A, Mei X, Huang M, Yang Y, Fayad ZA. Chest CT findings in coronavirus disease-19 (COVID-19): relationship to duration of infection. Radiology. 2020;295(3):685-91. https:// doi.org/10.1148/radiol.2020200463.

4. No Title 2020. https://www.who.int/emergencies/diseases/novelcoronavirus-2019?gclid=EAIaIQobChMI6NbPzsq06gIVi ZOzCh3WAAXZEAAYASAAEgKSH_D_BwE.

5. Lei $\mathrm{S}$, et al. Clinical characteristics and outcomes of patients undergoing surgeries during the incubation period of COVID-19 infection. Elsevier. https://www.sciencedirect.com/science/arti cle/pii/S2589537020300754. Accessed 25 Aug 2020

6. Mobini M, Ghasemian R, Larijani LV, Mataji M, Maleki I. Vasculitis-Associated Auto-antibodies and Complement Levels in patients with COVID-19 Infection 2020. https://doi.org/10. 21203/rs.3.rs-30488/v1.

7. Shen $\mathrm{B}$, et al. Proteomic and metabolomic characterization of COVID-19 patient sera. Elsevier. https://www.sciencedirect.com/ science/article/pii/S0092867420306279. Accessed 25 Aug 2020

8. Noris M, Benigni A, Remuzzi G. The case of Complement activation in COVID-19 multiorgan impact. Kidney International. Elsevier 2020. https://www.sciencedirect.com/science/article/pii/ S0085253820305561. Accessed 25 Aug 2020

9. Mastaglio S, Ruggeri A, Risitano AM, Angelillo P. The first case of COVID-19 treated with the complement C3 inhibitor AMY101. Clin Immunol. Elsevier, 2020. https://www.sciencedirect. com/science/article/pii/S1521661620303314. Accessed 25 Aug 2020

10. Giang J, Seelen MA, van Doorn M, Rissmann R, Prens EP, Damman J. Complement activation in inflammatory skin diseases. Front Immunol. 2018;9:639. https://doi.org/10.3389/ fimmu.2018.00639.

11. Java A, et al. The complement system in COVID-19: friend and foe? JCI insight. 2020;5:15. https://doi.org/10.1172/jci.insight. 140711.

12. Merle NS, Noe R, Halbwachs-Mecarelli L, Fremeaux-Bacchi V, Roumenina LT. Complement system part II: role in immunity. Front Immunol. 2015;6:257. https://doi.org/10.3389/fimmu.2015. 00257.

13. Gralinski LE, et al. Complement activation contributes to severe acute respiratory syndrome coronavirus pathogenesis downloaded from. Am Soc Microbiol. 2018. https://doi.org/10.1128/mBio. 01753-18.

14. Jiang $\mathrm{Y}$, et al. Blockade of the $\mathrm{C} 5 \mathrm{a}-\mathrm{C} 5 \mathrm{aR}$ axis alleviates lung damage in hDPP4-transgenic mice infected with MERS-CoV. Emerg Microbes Infect. 2018;7:1. https://doi.org/10.1038/ s41426-018-0063-8.

15. Delanghe JR, De Buyzere ML, Speeckaert MM. Letter to the editor $\mathrm{C} 3$ and ACE1 polymorphisms are more important confounders in the spread and outcome of COVID-19 in comparison with ABO polymorphism. Eur J Prev Cardiol. 2020 ;27(12):1331-2. https://doi.org/10.1177/2047487320931305.
16. Harapan H, et al. Coronavirus disease 2019 (COVID-19): a literature review. J Infect Public Health. 2020;13(5):667-73. https://doi.org/10.1016/j.jiph.2020.03.019.

17. Forouzesh M, Rahimi A, Valizadeh R, Dadashzadeh N, Mirzazadeh A. Clinical display, diagnostics and genetic implication of novel coronavirus (COVID-19) epidemic. Eur Rev Med Pharmacol Sci. 2020;24(8):4607-15. https://doi.org/10.26355/eurrev_ 202004_21047.

18. Zimmermann $\mathrm{P}$, Curtis N. Coronavirus infections in children including COVID-19: an overview of the epidemiology, clinical features, diagnosis, treatment and prevention options in children' Pediatr Infect Dis J. 2020 https://www.ncbi.nlm.nih.gov/pmc/ articles/PMC7158880/. Accessed 26 Oct 2020.

19. Cao J, et al. Clinical features and short-term outcomes of 102 patients with coronavirus disease 2019 in Wuhan, China. Clin Infect Dis. 2020;71(15):748-55. https://doi.org/10.1093/cid/ ciaa243.

20. Wan S, Xiang Y, Fang W, Zheng Y, Boqun L. Clinical features and treatment of COVID-19 patients in northeast Chongqing. J Med Virol. 2020. https://doi.org/10.1002/jmv.25783.

21. Yang J, Zheng Y, Gou X, Pu K, Chen Z. Prevalence of comorbidities and its effects in patients infected with SARS-CoV-2: a systematic review and meta-analysis, Int J Infect Dis. 2020. ijidonline.com. https://www.ijidonline.com/article/S1201-9712(20) 30136-3/abstract. Accessed 05 Jan 2021

22. Felger J, Haroon E, Patel T, Goldsmith DR. What does plasma CRP tell us about peripheral and central inflammation in depression?. Mol Psychiatry. 2020. nature.com. https://www.nat ure.com/articles/s41380-018-0096-3. Accessed 10 May 2021

23. Chen W, Zheng KI, Liu S, Yan Z, Xu C, Qiao Z. Plasma CRP level is positively associated with the severity of COVID-19. Ann Clin Microbiol Antimicrob. 2020;19:18. https://doi.org/10.1186/ s12941-020-00362-2.

24. Sahu B, Kampa R, Padhi A, Aditya KP. C-reactive protein: a promising biomarker for poor prognosis in COVID-19 infection. Clinica Chimica Acta. Elsevier, 2020. https://www.sciencedirect. com/science/article/pii/S0009898120302771. Accessed 10 May 2021.

25. Herold T, Jurinovic V, Arnreich C, Brian JL. Elevated levels of IL-6 and CRP predict the need for mechanical ventilation in COVID-19. J Allergy Clin Immunol. Elsevier, 2020. https:// www.sciencedirect.com/science/article/pii/S0091674920306850. Accessed 10 May 2021

26. Bosmann M. Complement activation during critical illness: current findings and an outlook in the era of COVID-19. Am J Respir Crit Care Med. 2020;202(2):163-5. https://doi.org/10.1164/rccm. 202005-1926ED.

27. Song W-C, Fitzgerald GA. COVID-19, microangiopathy, hemostatic activation, and complement. J Clin Investig. 2020. https:// doi.org/10.1172/JCI140183.

28. Diao B, et al. Human kidney is a target for novel severe acute respiratory syndrome coronavirus 2 (SARS-CoV-2) infection. Medrxiv. 2020. https://doi.org/10.1101/2020.03.04.20031120.

29. Gao T, Hu M, Xiaopeng Z. Highly pathogenic coronavirus $\mathrm{N}$ protein aggravates lung injury by MASP-2-mediated complement over-activation. Medrxiv. 2020;25:777.

30. Conigliaro P, Triggianese P, Perricone C, Chimenti MS, Perricone R, Reumatologia A. COVID-19: disCOVering the role of complement system.https://coronavirus.jhu.edu/map.html, Accessed 25 Aug 2020

31. El-Shamy A, Branch AD, Schiano TD, Gorevic PD. The complement system and $\mathrm{C} 1 \mathrm{q}$ in chronic hepatitis $\mathrm{C}$ virus infection and mixed cryoglobulinemia. Front Immunol. 2018. https://doi.org/ 10.3389/fimmu.2018.01001. 
32. Ravelli A, Cassola G, Gattorno M. Complement activation in patients with COVID-19: A\&nbsp;novel therapeutic target. Elsevier, 2020. https://doi.org/10.7326/L20-0227

33. Pitts TC. A preliminary update to the Soliris to stop immune mediated death in Covid-19 (SOLID-C19) compassionate use study.Hudson Med. 2020.

34. Diurno F, Numis F, Porta G, Cirillo F. Eculizumab treatment in patients with COVID-19: preliminary results from real life ASL Napoli 2 Nord experience. Eur Review Med Pharmacol Sci. europepmc.org, 2020. https://europepmc.org/article/med/32329881. Accessed 25 Aug 2020

35. Merzon E, et al. Low plasma $25(\mathrm{OH})$ vitamin D level is associated with increased risk of COVID-19 infection: an Israeli population-based study. FEBS J. 2020;287(17):3693-702. https://doi. org/10.1111/febs.15495.
36. Rhodes JM, Subramanian S, Laird E, Griffin G, Kenny RA, Rhodes AJ. Perspective: vitamin D deficiency and COVID-19 severity-plausibly linked by latitude, ethnicity, impacts on cytokines, ACE2 and thrombosis. Wiley Online Libr. 2020. https://doi.org/10.1111/joim.13149.

37. Ali N. Role of vitamin D in preventing of COVID-19 infection, progression and severity. J Infect Public Health. 2020; 13(10):1373-80. https://doi.org/10.1016/j.jiph.2020.06.021.

38. Grant WB, et al. Evidence that vitamin D supplementation could reduce risk of influenza and COVID-19 infections and deaths. Nutrients. 2020. https://doi.org/10.3390/nu12040988.

Publisher's Note Springer Nature remains neutral with regard to jurisdictional claims in published maps and institutional affiliations. 